\title{
Structural and functional properties of the corpus luteum of pregnancy
}

\author{
H. R. Sawyer \\ Animal Reproduction and Biotechnology Laboratory, Department of Physiology. \\ Colorado State University, Fort Collins, CO 80523, USA
}

In domestic ruminants the parenchyma of the corpus luteum consists of two subpopulations of steroidogenic cells commonly referred to as small and large luteal cells. These cells differ not only in size and structural characteristics, but also in functional properties. During the mid-luteal phase of the oestrous cycle approximately $60 \%$ of the corpus luteum is occupied by steroidogenic cells. Although the steroidogenic capacity of these cells declines as pregnancy advances, the cells persist as distinct populations throughout pregnancy and for several days following parturition. In general, structural changes typically observed at the end of the oestrous cycle also occur after parturition, but over a more extended period. These include deletion of endothelial cells and occlusion of capillary lumina with cellular debris and apoptotic bodies, an infiltration of eosinophils and macrophages, and fragmentation and lysis of parenchymal cells. However, not all parenchymal cells undergo lysis, nor are they rapidly phagocytosed by macrophages. Instead, many fuse to form what appear to be large syncytia that contain numerous lipid droplets, tightly packed mitochondria and multiple nuclei with condensed chromatin. Fusion of parenchymal cells to form syncytial profiles begins $2-3$ days after parturition and the syncytia persist for at least 22 days post partum. By day 35 post partum transformation of the corpus luteum into a corpus albicans is essentially complete.

\section{Introduction}

In domestic ruminants, as in other animals, the corpus luteum of the oestrous cycle and pregnancy comprises three distinct cell types: parenchymal (i.e. steroidogenic) cells, fibroblasts and capillary endothelial cells. On the basis of differences in size, morphology and biochemistry, cells that form the parenchymal component of the corpus luteum can be further subdivided into at least two subpopulations (Ursely and Leymarie, 1979; Koos and Hansel, 1981; Fitz et al, 1982; Rodgers et al., 1983a; Niswender et al., 1985; O'Shea, 1987). One population consists of cells that are known as small luteal cells. These cells are presumed to be derived from cells of the theca interna of the follicle and have also been referred to as theca-lutein, paralutein and type 1 cells. Cells comprising the second population of parenchymal cells are derived from granulosa cells (O'Shea ef al., 1987) and are frequently referred to as large luteal cells. Alternative terms for large luteal cells include blossom, granulosa-lutein and type II cells. After ovulation, and as the corpus luteum matures, small luteal cells increase in number but not size, whereas large luteal cells increase in size but not number (Farin et al., 1986). Consequently, as the corpus luteum increases in mass and becomes functionally mature, the relative volume occupied by small and large luteal cells remains stable until luteolysis is initiated, either at the end of the oestrous cycle in nonpregnant animals, or near the time of parturition in pregnant animals. Although both cell types synthesize and secrete progesterone and possess receptors for LH, differences in basal and LH-stimulated 
secretion of progesterone between small and large luteal cells have been consistently observed (Niswender et al., 1985). Small luteal cells isolated from ovine (Fitz et al., 1982; Rodgers et al, 1983a; Harrison et al., 1987) and bovine (Ursely and Leymarie, 1979; Koos and Hansel, 1981; Weber et al, 1987) corpora lutea during the mid-luteal phase of the oestrous cycle show marked increases (about 4-20 fold) in progesterone secretion when incubated in the presence of LH. In contrast, secretion of progesterone by large luteal cells is unaffected by LH. During pregnancy, small and large luteal cells retain the ability to synthesize and secrete progesterone, but the ability of small luteal cells to respond to LH appears to diminish gradually (Harrison et al., 1987; Weber et al, 1987; Farin et al., 1989). The underlying cause for this reduced responsiveness is not clear, as there is no concomitant reduction in the number of receptors for LH (Harrison et al., 1987; Farin et al., 1989).

At the end of the oestrous cycle, $\mathrm{PGF}_{2 a}$ is released from the uterus in discrete pulses and causes the corpus luteum to regress. Regression of the corpus luteum at this time is characterized by a reduction in blood flow (Nett et al, 1976), an infiltration of eosinophils and macrophages (Murdoch, 1987), an increase in autophagosomes within luteal cells (Gemmell et al, 1976; McClellan et al., 1977), and cytoplasmic and nuclear changes consistent with the process of apoptosis (O'Shea et al., 1977; Sawyer et al, 1990). Concomitant with these changes, there is a precipitous decline in circulating concentrations of progesterone. In contrast, during fertile cycles, the presence of a viable conceptus within the uterus prevents luteolysis, and serum concentrations of progesterone remain similar to those measured during the mid-luteal phase of the cycle. The corpus luteum is maintained for the duration of pregnancy in both sheep and cattle: however, in sheep the corpus luteum is not required for maintenance of pregnancy beyond day 50 of gestation, whereas removal or lysis of the corpus luteum in cattle anytime before day 200 of gestation results in termination of pregnancy.

\section{Structural Features of Small and Large Luteal Cells}

On the basis of differences in size and morphology, small and large luteal cells can be identified at the light microscope level at all stages of the oestrous cycle and throughout pregnancy. Not only do small and large luteal cells persist as distinct populations throughout pregnancy (O'Shea et al, 1979; O'Shea and McCoy, 1988), but they can also be discerned for several days after parturition (O'Shea and Wright, 1985). Structural changes that occur in the corpus luteum following parturition resemble those that occur at the end of the oestrous cycle; however, the overall process is much slower (O'Shea and Wright, 1985; O'Shea and McCoy, 1988). Structural characteristics of ovine parenchymal cells discernible by light microscopy at selected times during the reproductive cycle from day 12 after oestrus to day 35 post parturn are illustrated in Fig. $1(a-f)$.

\section{Light microscopy}

In most studies the diameters of small luteal cells in sheep (Rodgers et al., 1984; Farin et al., 1986; O'Shea et al., 1986) and cattle (Ursely and Leymarie, 1979; Weber et al, 1987; O'Shea ef al, 1989; Lei ef al., 1991) have been reported to range from 12 to $22 \mu \mathrm{m}$. The cytoplasm of these stellate cells contains lipid droplets and usually stains darker than does the cytoplasm of large luteal cells (Fig. 1a, b). However, near the end of pregnancy and following parturition, the cytoplasmic density of large luteal cells appears similar to that for small luteal cells (Fig. Ic, d). In addition to size, shape and cytoplasmic features, a unique structural characteristic that can be used to identify ovine small luteal cells, both by light and electron microscopy, is the presence of nuclei with conspicuous cytoplasmic inclusions (Fig. 1c). Approximately $9 \%$ of ovine small luteal cells contain these inclusions (O'Shea and McCoy, 1988). Similar inclusions are not normally observed in nuclei of large luteal cells.

The mean diameter of large luteal cells in sheep (Farin et al., 1986) and cattle (O'Shea et al., 1989) during the mid-luteal phase of the oestrous cycle were 31 and $38 \mu \mathrm{m}$, respectively. In contrast to small luteal cells, large luteal cells are usually spherical or polyhedral and contain a large spherical nucleus with prominent nucleoli. The cytoplasm of large luteal cells through midpregnancy appears pale compared to that of small luteal cells, and in sheep generally lacks lipid droplets until the onset of luteolysis. Although 

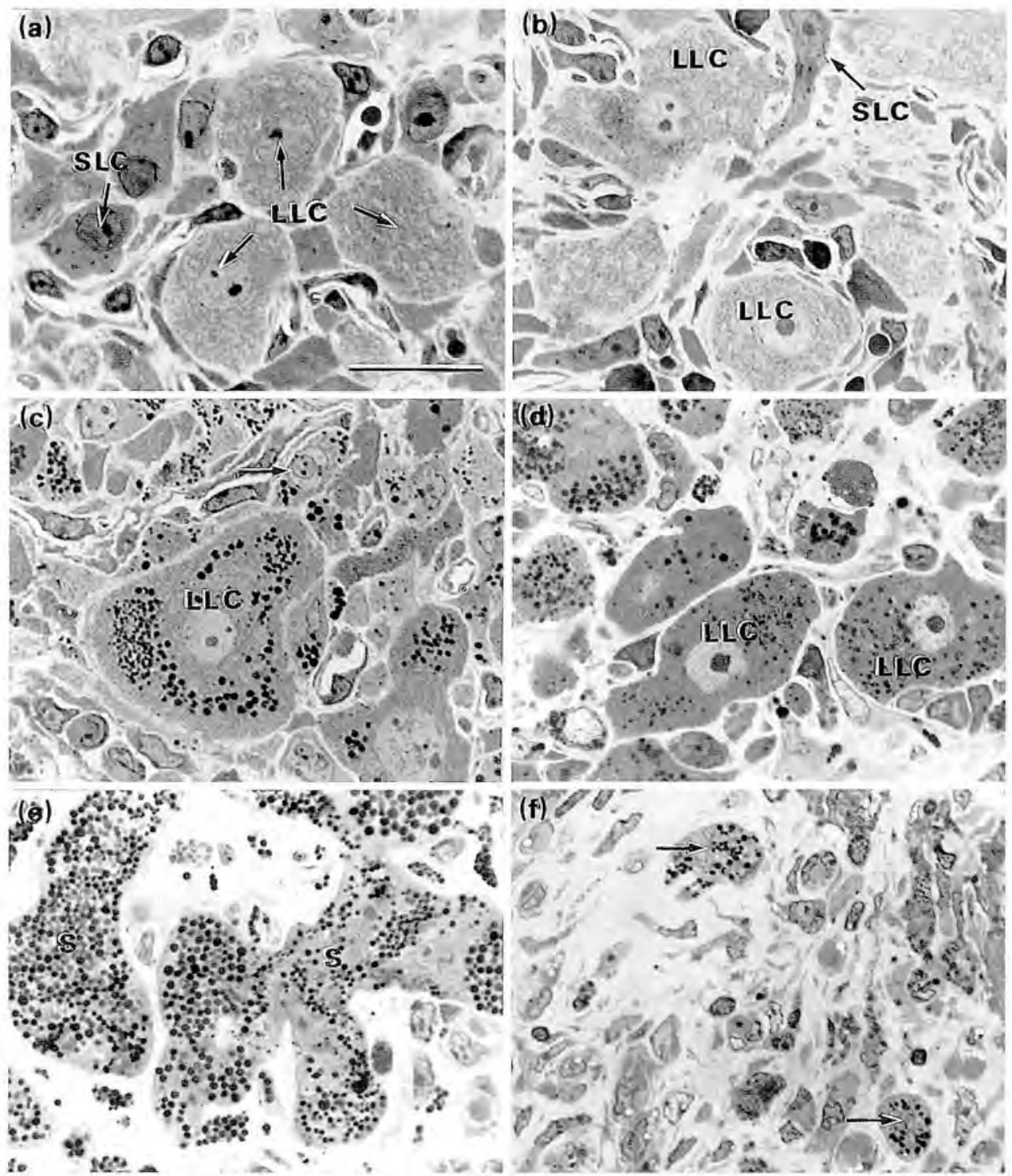

Fig. 1. Light micrographs illustrating the appearance of small (SLC) and large (LLC) luteal cells in corpora lutea during the oestrous cycle, pregnancy and post partum. All photomicrographs were prepared from luteal tissues that had been immersion fixed in a solution of $4 \%$ glutaraldehyde and $0.1 \mathrm{~mol}$ cacodylate buffer $\mathrm{I}^{-1}$ ( $\left.\mathrm{pH} 7.4\right)$, postfixed in $1 \%$ osmium tetroxide, embedded in Polybed 812 resin, sectioned at a thickness of $1 \mu \mathrm{m}$, and stained with Toluidine blue. (a) Day 12 of the oestrous cycle; (b) day 16 of pregnancy; (c) $1 \mathrm{~h}$ post partum. The cytoplasmic density of small and large luteal cells is similar at this time and substantial amounts of lipid are present in the cytoplasm of both cell types. Small luteal cells can easily be distinguished by the presence of nuclear inclusions of cytoplasm (arrow); (d) day 3 post partum. In many areas of the corpus luteum large luteal cells appear healthy, and except for the accumulation of lipid there are no overt signs of degeneration. In other areas some cells appear to be degenerating, and in others cells appear to fuse to give rise to syncytia; (e) day 22 post partum. Beginning as early as day 2 post partum some luteal cells appear to fuse and give rise to large syncytia $(S)$; (f) day 35 post partum. Transformation of the corpus luteum into a corpus albicans is essentially complete, but remnants of luteal cells containing lipid droplets (arrows) are still detectable. Scale bar represents $30 \mu \mathrm{m}$. 


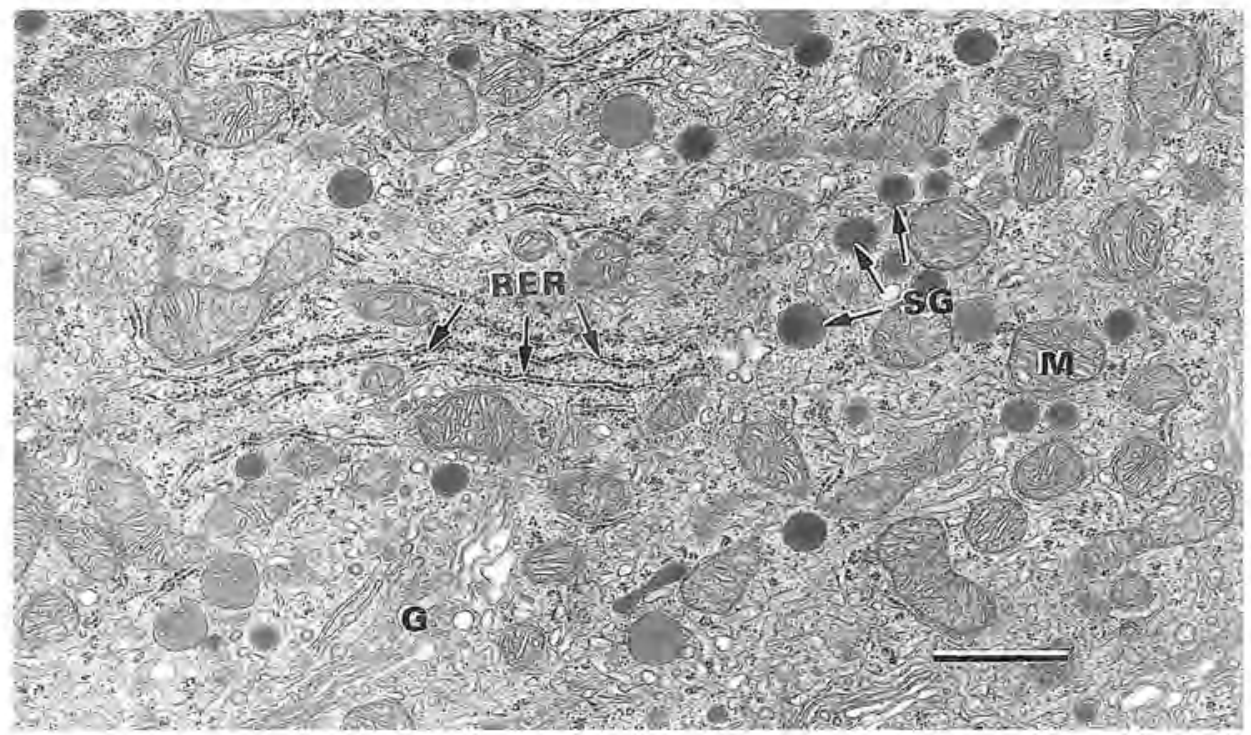

Fig. 2. Electron micrograph of a portion of the cytoplasm of an ovine large luteal cell on day 12 of the oestrous cycle. The cytoplasm contains numerous secretory granules (SG), mitochondria (M), isolated stacks of rough endoplasmic reticulum (RER) and an elaborate Golgi apparatus (G). Scale bar represents $1 \mu \mathrm{m}$.

it is relatively easy to identify ovine small and large luteal cells under the light microscope (Fig. Ia-c), the task is more difficult in cattle (O'Shea, 1987) because lipid droplets are present in both small and large luteal cells in cattle. Since the presence or absence of cytoplasmic lipid droplets cannot be used to distinguish between bovine small and large luteal cells accurately (O'Shea et al, 1990), identification of these cells using bright field optics and conventional staining techniques is primarily limited to size, shape and cytoplasmic density. With the exception of the accumulation of lipid in ovine large luteal cells at the end of pregnancy (Fig. Ic, d), the morphology of steroidogenic luteal cells during gestation is very similar to that typically observed during the mid-luteal phase of the oestrous cycle (Weber et al., I987; O'Shea et al., 1989).

\section{Electron microscopy}

The ultrastructure of small and large luteal cells were examined extensively in sheep (O'Shea et al., 1979; Paavola and Christensen, 1981) and cattle (Fields and Fields, 1985; O'Shea et al., 1990). Consistent with a steroidogenic function, the cytoplasm of these cells is characterized by an abundance of smooth endoplasmic reticulum and numerous mitochondria. The volume density and number of mitochondria are greater in large cells than in small cells and may account for the higher basal production of progesterone by large luteal cells (Kenny et al., 1989). A variety of ultrastructural characteristics can be used to distinguish between small and large luteal cells (Box 1), but the most obvious and reliable is the presence of electron-dense secretory granules in large luteal cells (Fig. 2). These granules are approximately $0.2 \mu \mathrm{m}$ in diameter (Gemmell et al, 1974; Paavola and Christensen, 1981) and have been shown to contain oxytocin (Theodosis et al., 1986; Fields et al., 1992). In sheep, secretory granules are dispersed throughout the cytoplasm of large luteal cells (Fig. 2), whereas in cattle they often occur in clusters (Fields et al., 1985; O'Shea et al., 1990) (Fig. 3). The cytoplasm of small luteal cells (Fig. 4) typically lacks secretory granules, but contains an abundance of smooth endoplasmic reticulum, numerous lipid droplets and what appear to be secondary lysosomes and multivesicular bodies. Since the shape of the nuclei in small luteal cells is very irregular in outline and appears to be folded in some areas, characteristic 'nuclear 
Box 1. Ultrastructural characteristics of parenchymal cells in sheep and cattle

\section{Structure/Organelle}

Nucleus

Plasma membrane

Basal lamina

Secretory granules

Lysosomes

Lipid droplets

Mitochondria

Golgi apparatus

\section{Characteristics}

The nuclear membrane in oyine small cells is often irregular in shape and characterized by conspicuous infoldings. As a result, and depending upon the plane of section, nuclei in approximately $9 \%$ of small cells appear to have cytoplasmic inclusions. The nucleus in large cells is usually spherical and lacks cytoplasmic inclusions.

In contrast to small cells, many areas of the plasma membrane in large cells are highly folded giving rise to what appear to be microvilli. Many of the microvillus extensions penetrate the surrounding basal lamina and make contact with neighbouring cells, whereas others fold back and make contact with the plasma membrane or adjacent microvilli of the same cell. Adherens and septate-like junctions are present, but observed more frequently in cattle than in sheep. There is no morphological evidence for classical gap junctions between parenchymal cells.

Large cells are surrounded by a prominent basal lamina that in most cases appears to be continuous. The basal lamina associated with small cells is less well defined and is absent along some regions of the cell surface.

A major distinguishing feature between small and large cells is the presence of numerous, electron-dense secretory granules in the cytoplasm of large cells. These granules are about $0,2 \mu \mathrm{m}$ in diameter and contain oxytocin. Although small cells occasionally have similar granules, they are very rare and do not appear to be released by exocytosis. In cattle, secretory granules often occur in conspicuous clusters.

Lysosomes, as well as multivesicular bodies, are present in both cell types. Before the onset of luteolysis they appear to be more numerous in small luteal cells than in large cells.

Regardless of the stage of the cycle examined, small luteal cells contain many large lipid droplets. Ovine large cells have very few lipid droplets until the onset of luteolysis, at which time lipid droplets begin to accumulate. Bovine large luteal cells have lipid droplets at all stages examined.

Rod-shaped crystalline inclusions of unknown composition are sometimes present in boyine mitochondria. Small matrix granules have been observed at all stages in both species. During the later stages of pregnancy, large electron-dense granules accumulate within the matrix of mitochondria in large luteal cells.

Both cell types have elaborate and multiple Golgi networks. In large cells it is apparent that the Golgi apparatus is involved in the formation of secretory granules. This is the primary distinguishing feature with respect to the Golgi apparatus, since there are numerous vesicles (both smooth and coated) associated with the cis and trans elements in both cell types.

Descriptions based on personal observations and electron micrographs published by O'Shea (1979, 1987); Fields et al. (1985, 1992) and O'Shea of al (1990).

inclusions' of cytoplasm (Fig. 4) probably reflect a plane of section through a finger-like projection of cytoplasm into a fold in the nuclear membrane. Consistent with this interpretation, O'Shea (1987) has provided evidence for direct continuity between profiles of cytoplasm observed within the nucleus and the cytoplasm proper.

Although small and large luteal cells in sheep and cattle have many features in common, it should be noted that bovine parenchymal cells have several unique features (Fields and Fields, 1985; O'Shea et al., 1990; Fields et al., 1992): (i) both cell types possess numerous lipid droplets during all stages of the 


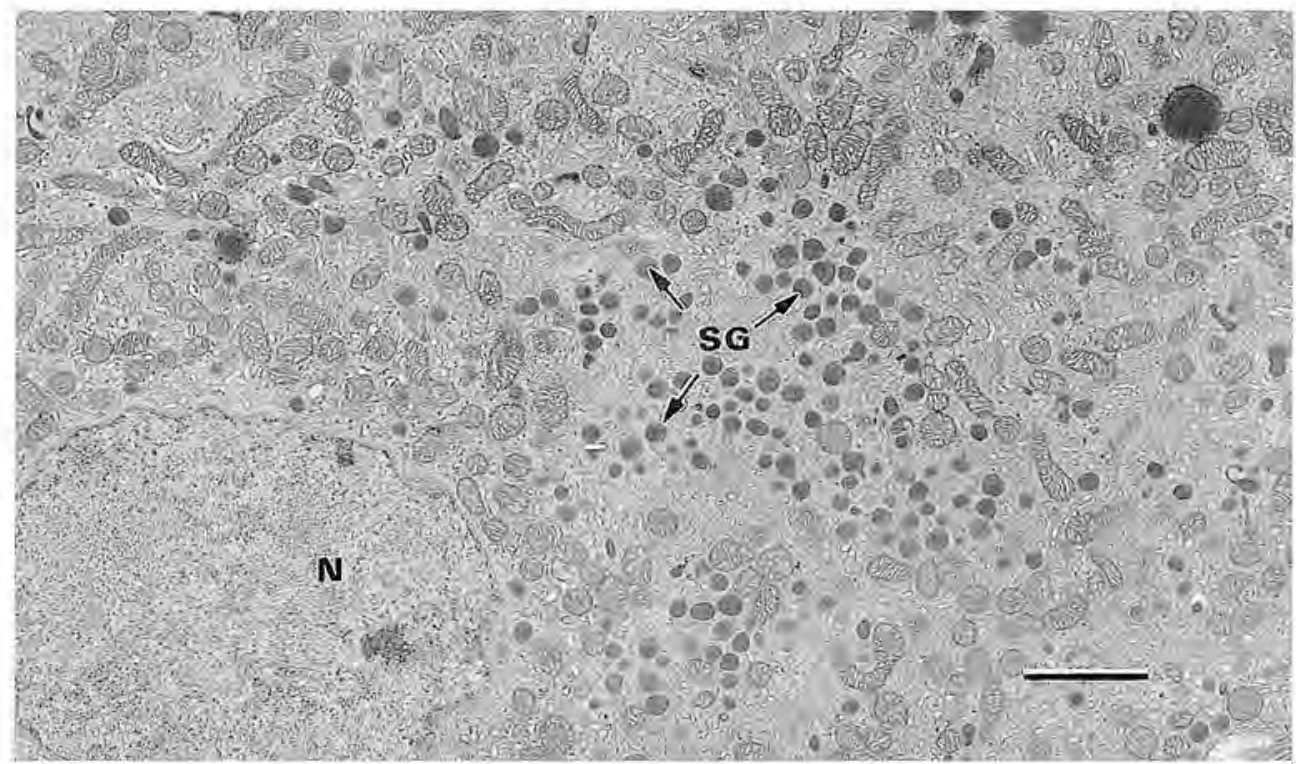

Fig. 3. Electron micrograph of a portion of a bovine large luteal cell on day 12 of the oestrous cycle. A unique feature of bovine large luteal cells is the arrangement of secretory granules (SG) into clusters. These clusters are often in close proximity to the nucleus $(\mathrm{N})$. Scale bar represents $2 \mu \mathrm{m}$.

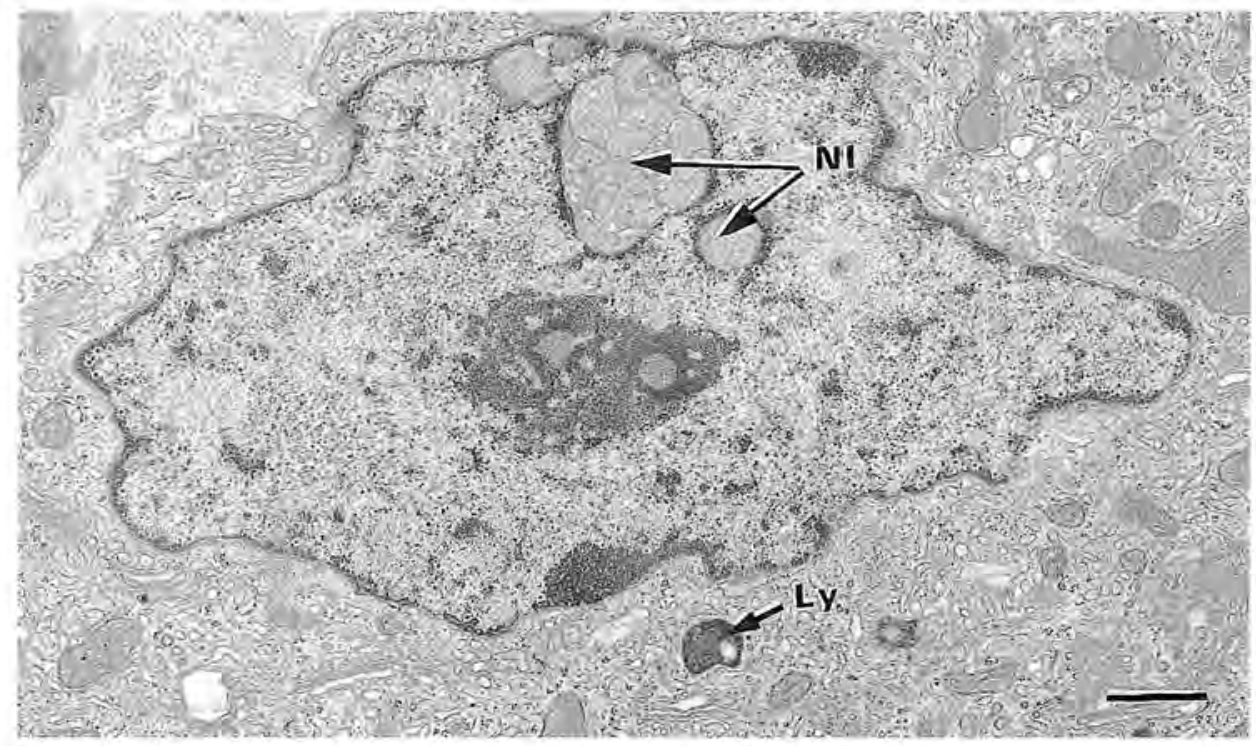

Fig. 4. A portion of an ovine small luteal cell showing inclusions (NI) of cytoplasm within the nucleus. The cytoplasm of small luteal cells contains lysosomal structures (Ly) but lacks secretory granules. Scale bar represents $1 \mu \mathrm{m}$.

reproductive cycle; (ii) elements of the smooth endoplasmic reticulum are occasionally arranged in whorls, sometimes enveloping lipid droplets; (iii) ring-shaped mitochondria are frequently observed; (iv) some mitochondria contain crystalline inclusions; and (v) secretory granules present in large luteal cells are sometimes arranged in discrete clusters. 


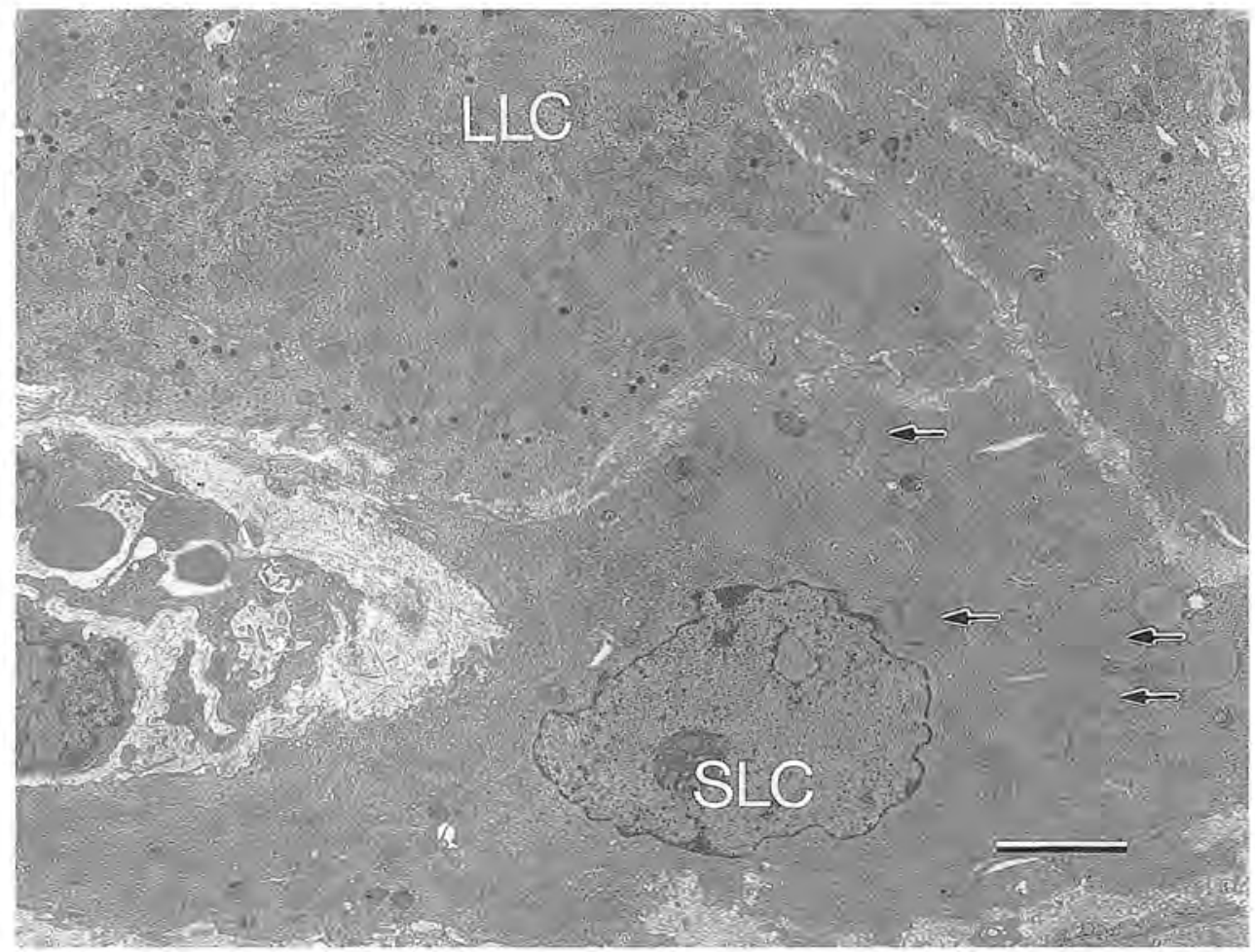

Fig. 5. Electron micrograph illustrating the general ultrastructural features of small (SLC) and large (LLC) luteal cells during the mid-luteal phase of the oestrous cycle. Large luteal cells contain numerous secretory granules and are usually devoid of lipid droplets. Conversely, small luteal cells lack secretory granules but contain numerous lipid droplets (arrows). Scale bar represents $4 \mu \mathrm{m}$.

\section{Changes in the Corpus Luteum During Pregnancy}

\section{Structure of parenchymal cells}

Most of the structural characteristics of small and large luteal cells during the mid-luteal phase of the oestrous cycle (Fig. 5) are maintained throughout pregnancy (O'Shea et al., 1979; Weber et al., 1987; O'Shea and McCoy, 1988). Although signs of involution (for example weight loss, small focal areas with degenerating cells) are detectable before parturition (O'Shea and McCoy, 1988), parenchymal cells in many areas appear healthy and exhibit no overt signs of degeneration several days after parturition (Fig. 6).

\section{Cellular composition}

Morphometric techniques have been used in several electron microscope studies to obtain quantitative data regarding the cellular composition of corpora lutea in sheep (Rodgers et al., 1984; Farin et al., 1986; O'Shea et al., 1986) and cattle (O'Shea et al., 1989) during selected stages of the oestrous cycle, but application of these techniques to evaluate the cellular composition during defined stages of pregnancy is limited to one study in sheep (O'Shea and McCoy, 1988). On the basis of results obtained by Farin et al. (1986), it is evident that after ovulation small luteal cells increase in number but not size, whereas large luteal cells increase in size but not number. Although volume densities and diameters of parenchymal cells remain relatively stable from day 12 to day 142 of pregnancy, there appears to be a 


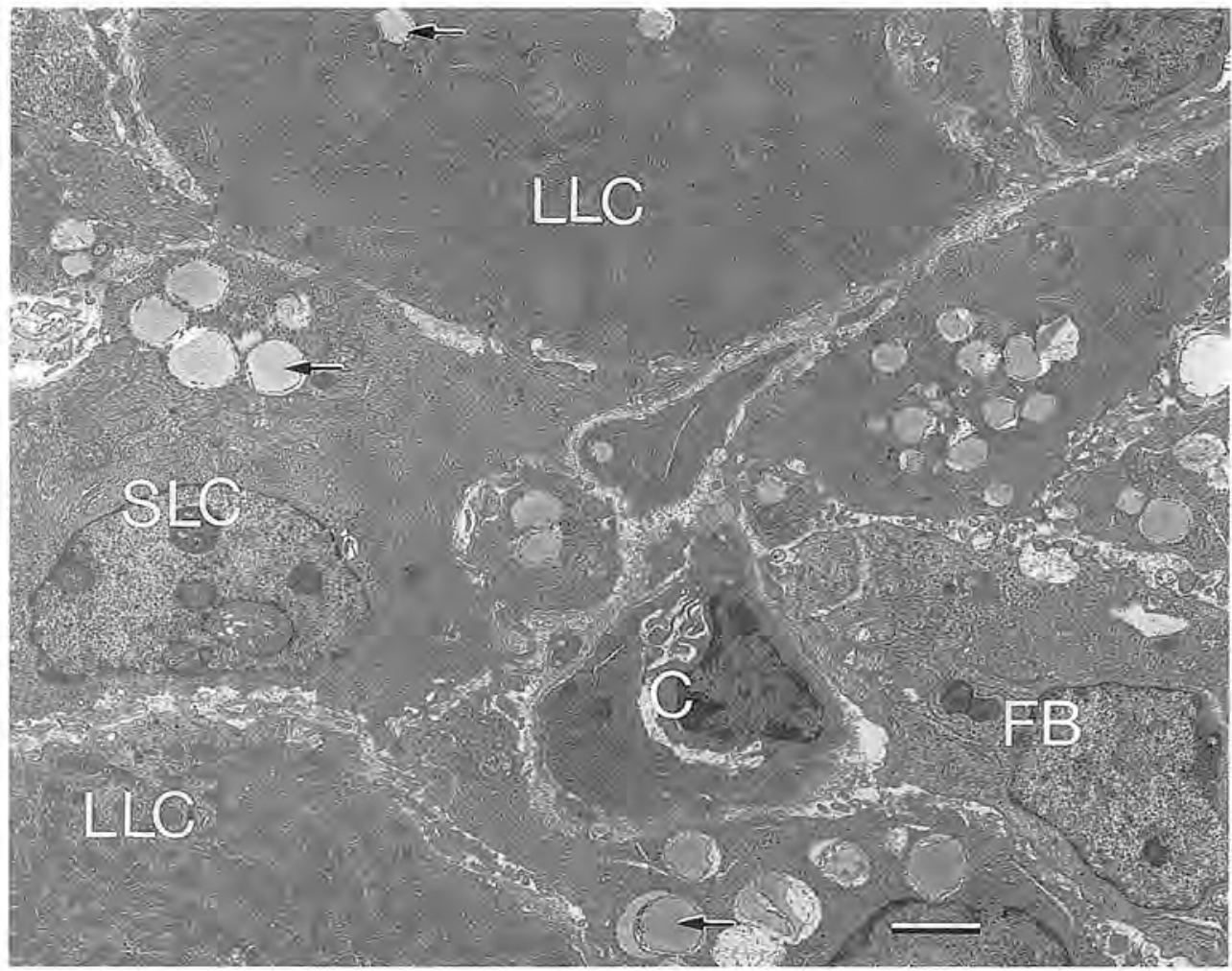

Fig. 6. Portion of an ovine corpus luteum I h after parturition. All of the normal cellular components present during the mid-luteal phase of the oestrous cycle are present (small luteal cell, SLC; large luteal cell, LLC; capillary, C; fibroblast, FB). Minor signs of involution include the accumulation of lipid droplets (arrows) and compact arrangement of mitochondria within the cytoplasm of large luteal cells. Scale bar represents $2 \mu \mathrm{m}$.

slight increase in the diameter of ovine large luteal cells after day 25 (Farin et al., 1989) (Table 1). During the mid-luteal phase of the cycle, approximately $55 \%$ of the corpus luteum is occupied by steroidogenic cells, compared with approximately $61 \%$ (range 59-62\%) from day 30 to day 142 of pregnancy. Thus, even though in sheep the corpus luteum is not required after day 50 of pregnancy, there is very little change in the parenchymal component and small and large luteal cells are maintained as distinct populations. Data regarding changes in the cellular composition of the bovine corpus luteum during pregnancy are not available, but on day 12 of the oestrous cycle the volume densities of small and large luteal cells were found to be $27.7 \pm 6.3$ and $40.2 \pm 7.0 \%$, respectively (O'Shea et al., 1989).

Hypotheses regarding the origin and fate of parenchymal cells that comprise the corpus luteum have been thoroughly reviewed by Niswender et al. (1985) and O'Shea (1987). There is general agreement that small and large luteal cells are initially derived from theca and granulosa cells, respectively; however, there is controversy regarding the suggestion that small luteal cells subsequently differentiate, or transform, into large luteal cells during the oestrous cycle and pregnancy. The strongest evidence in favour of this concept is that provided by Alila and Hansel (1984). Using monoclonal antibodies specific for theca and granulosa cells, respectively, they found that after ovulation the percentage of large luteal cells to which the granulosa-specific antibody bound progressively declined through day 100 of pregnancy. Conversely, the percentage of large luteal cells that bound the theca-specific antibody increased up to day 12 and remained unchanged through midpregnancy. On the basis of these findings, they concluded that as the corpus luteum matures, large luteal cells originally derived from granulosa 
Table 1. Volume density, number and diameter (mean \pm SEM) of ovine steroidogenic luteal cells during the oestrous cycle and pregnancy

\begin{tabular}{|c|c|c|c|c|c|c|}
\hline \multirow[b]{2}{*}{ Cell type } & \multicolumn{2}{|c|}{ Day of cycle ${ }^{a}$} & \multicolumn{4}{|c|}{ Day of pregnancy ${ }^{b}$} \\
\hline & 4 & 12 & 30 & 60 & 100 & 142 \\
\hline \multicolumn{7}{|l|}{ Small luteal cells } \\
\hline Volume density (\%) & $15 \pm 1$ & $23 \pm 2$ & $18 \pm 2$ & $22 \pm 3$ & $22 \pm 3$ & $18 \pm 7$ \\
\hline Number $\left(\times 10^{\circ}\right)$ & $10 \pm 3$ & $46 \pm 6$ & - & - & - & - \\
\hline Diameter $(\mu \mathrm{m})$ & $17 \pm 1$ & $18 \pm 1$ & 17 & 18 & 19 & 18 \\
\hline \multicolumn{7}{|l|}{ Large luteal cells } \\
\hline Volume density $(\%)$ & $39 \pm 4$ & $33 \pm 3$ & $41 \pm 5$ & $40 \pm 6$ & $40 \pm 4$ & $41 \pm 4$ \\
\hline Number $\left(\times 10^{6}\right)$ & $12 \pm 2$ & $15 \pm 3$ & - & - & - & - \\
\hline Diameter $(\mu \mathrm{m})$ & $22 \pm 1$ & $31 \pm 1$ & 37 & 37 & 38 & 36 \\
\hline
\end{tabular}

'Data summarized from Farin et al. (1986). 'Data summarized from O'Shea and McCoy (1988). Diameters were calculated from data reported for cell volume.

cells are replaced by small luteal cells that differentiate into large luteal cells. Additional evidence to support this concept comes from a study performed by Farin et al. (1988) in which the numbers and volume densities of small and large luteal cells in normally cyclic ewes were compared with those for normally cyclic ewes that had been treated with LH. Compared with untreated ewes, the number and volume density of large luteal cells in LH-treated ewes increased and was paralleled by a concomitant decrease in the number and volume density of small luteal cells. These observations strongly suggest that small luteal cells do in fact have the potential to develop into large luteal cells. In addition, there is also evidence suggesting that there is a unique population of cells (Type 5 cells) within bovine corpora lutea that may play a role in renewal of luteal cells (Spanel-Borowski et al, 1994). However, since the number of large luteal cells present at all stages during the lifespan of the corpus luteum can be accounted for on the basis of cells present at the onset of luteogenesis (O'Shea et al., 1987; O'Shea and McCoy, 1988), and in the absence of corroborative evidence for the presence of degenerating large luteal cells (i.e. those to be replaced), the concept that small luteal cells transform into large luteal cells remains controversial.

\section{Functional properties}

Progesterone secretion in vitro. Development and application of methods to dissociate corpora lutea into single cell suspensions and obtain relatively pure populations of small and large luteal cells by unit gravity sedimentation (Ursely and Leymarie, 1979; Koos and Hansel, 1981) and centrifugal elutriation (Fitz et al., 1982; Chegini et al., 1984) provided a means to evaluate individual functional properties of the two parenchymal cell types. Initially, efforts focused on the respective abilities of isolated small and large luteal cells to secrete progesterone in the presence or absence of LH and other secretagogues. Two consistent findings using parenchymal cells isolated from corpora lutea of ruminants during the oestrous cycle are (i) basal secretion of progesterone by large luteal cells is several times more than basal secretion by small luteal cells; and (ii) when small luteal cells are incubated in the presence of LH, secretion of progesterone increases by 4-20 times, whereas LH does not alter secretion of progesterone by large luteal cells (Ursely and Leymarie, 1979; Koos and Hansel, 1981; Fitz et al., 1982; Rodgers et al., 1983a; Weber et al, 1987). Direct comparisons between parenchymal cells isolated during the oestrous cycle versus pregnancy are limited, but it appears that during late pregnancy basal production of progesterone by bovine parenchymal cells is less than that for cells obtained during the oestrous cycle (Weber et al., 1987). In addition, secretion of progesterone by small luteal cells isolated from corpora lutea obtained 
during late pregnancy is not substantially enhanced in response to LH as is typical for small cells obtained during the mid-luteal phase of the oestrous cycle (Koos and Hansel, 1981). Basal secretion of progesterone by small and large luteal cells of sheep on day 25 and days 40-50 of pregnancy was not different from that of cells on day 10 of the oestrous cycle; however, the ability of small luteal cells to respond to LH had diminished (Harrison et al., 1987; Farin et al., 1989). The reason for this apparent reduction in sensitivity of small luteal cells to $\mathrm{LH}$ during pregnancy does not appear to be due to a reduction in the number of receptors for $\mathrm{LH}$. These data are consistent with the reported reduction in quantities of cytochrome $\mathrm{P}_{450} \mathrm{scc}_{\mathrm{sc}}$ and adrenodoxin in corpora lutea during late pregnancy (Rodgers et al., 1988) and provide evidence that as pregnancy progresses there is a reduction in steroidogenic capabilities.

Secretory granules, oxytocin and relaxin. In ruminants, it has been conclusively demonstrated that the corpus luteum produces and secretes oxytocin during the oestrous cycle (Wathes et al., 1983) and that oxytocin plays an important role in initiating luteolysis by stimulating the release of $\mathrm{PGF}_{2 u}$ from the uterus (Schams, 1989). On the basis of results from immunohistochemical (Guldenaar et al., 1984; Sawyer et al., 1986) and in vitro (Rodgers et al., 1983b; Harrison et al., 1987) studies, it is also apparent that production and secretion of oxytocin by the corpus luteum is restricted to large luteal cells. Similar to the synthesis, storage and release of oxytocin by hypothalamic neurones, in large luteal cells oxytocin is also synthesized as a prohormone (Ivell and Richter, 1984), packaged and stored in secretory granules and released at the cell surface via exocytosis (Theodosis et al., 1986; Fields et al, 1992) (Figs 2, 3).

Changes in populations of secretory granules in large luteal cells during the oestrous cycle and pregnancy of cattle have been examined (Fields et al, 1985, 1992). Not only are there stage-specific changes in the number of secretory granules, but there are also changes with respect to content. During the oestrous cycle, the number of oxytocin-containing secretory granules is greatest at approximately day 11. Thereafter, granules containing oxytocin are progressively depleted concomitant with involutive changes beginning at about day 14 after oestrus. During the early stages of pregnancy, granules containing oxytocin can be detected until day 25 , at which time they are depleted. From about day 45, a second population of granules emerges. This population gradually increases and maximum numbers are detected between day 180 and day 210 of pregnancy. Although the content(s) and function of granules in this second population are not known, they do not contain oxytocin (Fields et al, 1992). Similar granules in large luteal cells of pigs contain relaxin (Kendall et al., 1978; Fields and Fields, 1985) and relaxin immunoreactivity has been detected in bovine large luteal cells during late pregnancy (Fields et al, 1980). However, there are no studies that demonstrate the presence of relaxin in secretory granules in sheep or cattle, and efforts to detect a specific mRNA encoding relaxin in these ruminants have not been successful (Roche et al., 1993; Roche et al., 1994). On the basis of the reported effects of administration of porcine relaxin on induction of parturition in heifers (Musah et al., 1988), as well as effects on progesterone production by dispersed bovine luteal cells obtained at different stages of pregnancy (Musah et al., 1990), it appears that uterine and luteal receptors that can recognize relaxin are present. None the less, definitive evidence for a role of the corpus luteum in the production and secretion of relaxin in ruminants is not available.

\section{Luteolysis}

Luteolysis is a complex process by which the corpus luteum degenerates and is transformed into a nonfunctional corpus albicans. There are two well defined periods when luteolysis occurs. One occurs at the end of the oestrous cycle. Structural and functional changes at this time have been characterized and it has been demonstrated that $\mathrm{PGF}_{2 \alpha}$ is the initial luteolytic signal. The other period is at the end of gestation. Although the exact signal(s) for initiating luteolysis at this time is not known, changes in the structure and function of the corpus luteum are similar to those observed at the end of the oestrous. cycle, except that the overall degenerative process proceeds at a much slower rate. 


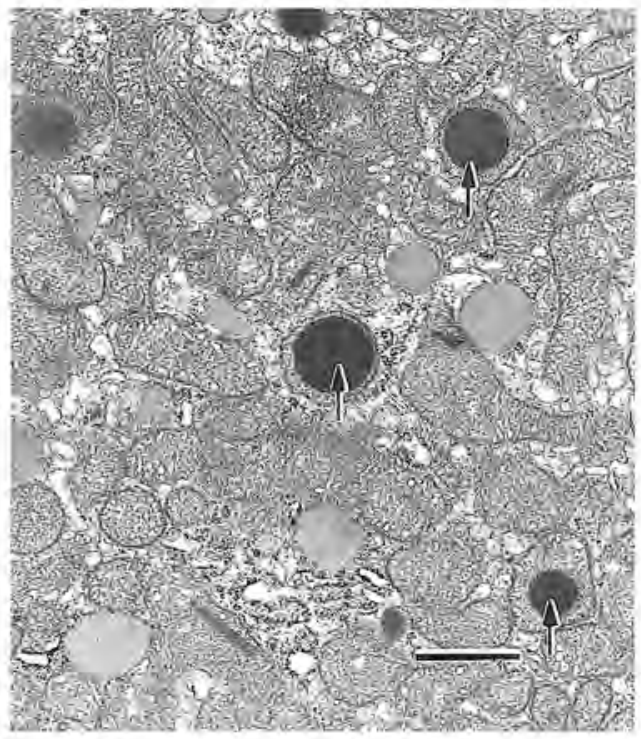

Fig. 7. Electron micrograph of a portion of an ovine large luteal cell on day 140 of pregnancy showing the presence of electron-dense inclusions (arrows) within the matrix of mitochondria. The appearance of matrix inclusions and compact arrangement of mitochondria serve as early signs that degenerative changes have been initiated. Scale bar represents $1 \mu \mathrm{m}$.

\section{Luteal regression during the oestrous cycle versus late pregnancy and post partum}

Oestrous cycle. Since the early 1970 s substantial evidence has accrued to indicate that the primary luteolysin in domestic ruminants is $\mathrm{PGF}_{2 a}$ (Knickerbocker ef al., 1988). Although the precise cellular mechanisms and sequelae that result in the demise of the corpus luteum are not completely understood, it is evident that during nonfertile cycles $\mathrm{PGF}_{2 a}$ from the uterus reaches the ovary via a veno-arterial transfer (Mapletoft and Ginther, 1975). In response to $\mathrm{PGF}_{2 a}$ there is a reduction in blood flow to the corpus luteum (Nett et al., 1976), an increase in autophagosomes within luteal cells (McClellan et al., 1977), an infiltration of eosinophils and macrophages (Murdoch, 1987), a reduction in mRNA for 33-hydroxysteroid dehydrogenase (Couet et al., 1990; Hawkins et al., 1993); degeneration of capillary endothelial cells and obstruction of capillary lumina (O'Shea et al., 1977) and general changes in the cytoplasm and nuclei of luteal cells that are consistent with the process of apoptosis (O'Shea et al, 1977; Sawyer et al., 1990). Thus, the process of luteolysis is complex and involves numerous changes, both structural and functional, all of which can contribute to the rapid decline in the production and secretion of progesterone.

Pregnancy and post partum. Luteal regression begins during late pregnancy as evidenced by a gradual decline in luteal mass and the presence of small numbers of degenerating cells in focal areas (O'Shea et al., 1979; O'Shea and McCoy, 1988; Weber et al., 1987). Quantitative data are not available, but there also appears to be a gradual increase in the number of mitochondria in parenchymal cells that contain large electron dense inclusions (Fig. 7). The composition of these mitochondrial granules is not known; however, since cytochrome $\mathrm{P} 450$ and adrenodoxin are substantially lower in corpora lutea during late pregnancy than during the mid-luteal phase of the oestrous cycle (Rodgers et al, 1988), it is possible that they simply reflect accumulation of cholesterol within individual mitochondria in which there has been a reduction in, or a total loss of, steroidogenic capabilities. 


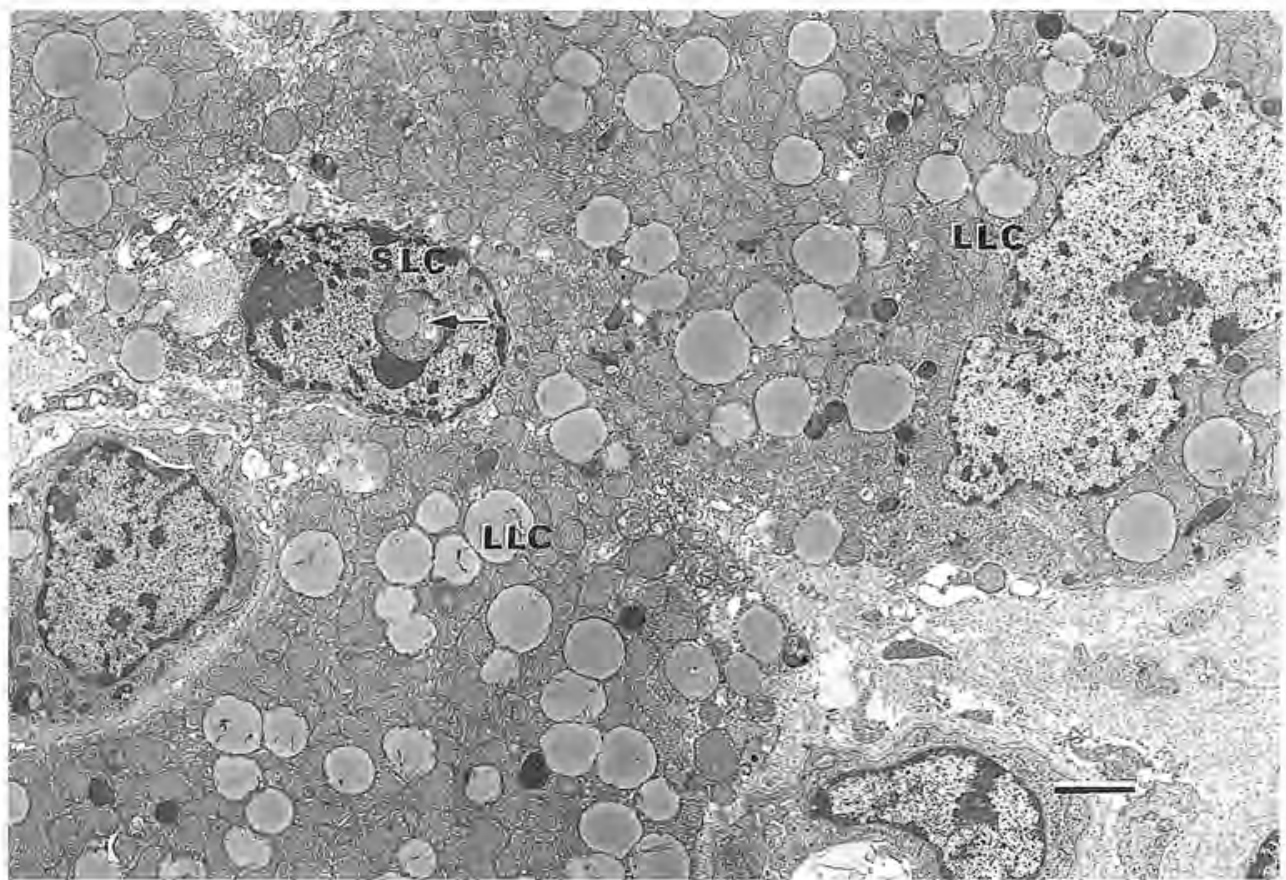

Fig. 8. Electron micrograph of a corpus luteum obtained 2 days after parturition showing what appears to be the fusion of two large luteal cells (LLC) and one small luteal cell (SLC). Note the inclusion of cytoplasm (arrow) within the nucleus of the small luteal cell. Scale bar represents $2 \mu \mathrm{m}$.

In general, all structural changes observed during luteolysis at the end of the oestrous cycle also occur following parturition, including deletion of capillary endothelial cells and occlusion of capillary lumina with cellular debris and apoptotic bodies, an infiltration of eosinophils and macrophages, fragmentation and lysis of parenchymal cells, vesiculation of the smooth endoplasmic reticulum, appearance of electron dense granules within the matrix of many mitochondria and depletion of secretory granules (O'Shea and Wright, 1985). However, there are at least two notable differences. First, the overall demise of the corpus luteum during late pregnancy and following parturition is much slower. Second, the formation of what appear to be syncytia (Fig. 1e), which often contain five or more nuclei and are up to $300 \mu \mathrm{m}$ in length. All of the syncytial profiles contain numerous lipid droplets, tightly packed mitochondria, multiple nuclei and appear to form as a result of fusion of parenchymal cells. Other organelles and derivatives of the endomembrane system are usually absent. Fusion of luteal cells to form these conspicuous syncytial profiles begins approximately 2-3 days after parturition (Fig. 8) and appears to continue for at least 22 days (Fig. 1e). By day 35 remnants of luteal cells are still detectable but most of the remaining tissue consists of fibrillar connective tissue components and blood vessels with thickened walls (Fig. If).

Because of the extended time required for the corpus luteum of pregnancy to undergo complete regression following parturition, the potential functions of the corpus luteum of pregnancy on subsequent reproductive function have been examined. Although removal of the corpus luteum before parturition does not shorten the interval to first oestrus after parturition (Campbell et al., 1994; Sawyer, unpublished), there is evidence that the corpus luteum of pregnancy contains a nonsteroidal aromatase inhibitor (Al-Gubory et al., 1994), can reduce follicular development and ovulation in response to hCG (Hall et al., 1993), and has an inhibitory effect on the pulsatile release of LH during the postpartum period (Al-Gubory et al., 1989). However, since there is no evidence that lysis or removal of the corpus luteum before parturition improves reproductive performance, the conclusion drawn by O'Shea and Wright (1985) " . . it seems unlikely that the CL of pregnancy serves any important function in the postpartum period" remains valid. 


\section{Conclusion}

Structural and functional properties of the corpus luteum of pregnancy are similar to those of the corpus luteum of the oestrous cycle. Small and large luteal cells persist as distinct populations throughout pregnancy and collectively occupy approximately $60 \%$ of the corpus luteum. Although there is a reduction in steroidogenic capabilities as pregnancy advances, the ability of small and large luteal cells to synthesize and secrete progesterone is maintained. There is no doubt that the primary function of the corpus luteum of pregnancy is to produce progesterone; however, the potential roles of other luteal factors in modulating endocrine and intraovarian functions during pregnancy and post partum warrant attention.

The assistance of C. Moeller and T. Nett, G. Niswender and C. Clay in the preparation of this manuscript is gratefully acknowledged.

\section{References}

Al-Gubory KH, Blanc MR and Marinet J (1989) Role of the corpus luteum of pregnancy in controlling pituitary gon. adotrophin secretion during the early post-partum period in the ewe Joumal of Reproduction and Fertility $\mathbf{8 6}$ 697-703

Al-Gubory KH, Driancourt M-A, Antoine M, Martal J and Neimer N (1994) Evidence that a non-steroidal factor from corpus luteum of pregnant sheep inhibits aromatase activity of ovarian follicles in vitro Journal of Reproduction and Fertility 100 51-56

Alila HW and Hansel W (1984) Origin of different cell types in the bovine corpus luteum as characterized by specific monoclonal antibodies Biology of Reproduction 31 10151025

Campbell JW, Hallford DM and Wise ME (1994) Serum progesterone and luteinizing hormone in ewes treated with $\mathrm{PGF}_{20}$ during mid-gestation plus gonadotrophin-releasing hormone after parturition Prostaglandins 47 333-344

Chegini N, Ramani N and Rao CV (1984) Morphological and biochemical characterization of small and large bovine luteal cells during pregnancy Molecular Cell Endocrinology $3789-102$

Couet J, Martel C, Dupont E, The VL., Sirard MA, Zhao HF, Pelletier G and Labrie F (1990) Changes in 3ßhydroxysteroid dehydrogenase/ $\Delta 5-\Delta 4$ isomerase messenger ribonucleic acid activity and protein levels during the estrous cycle in the bovine ovary Endocrinology 127 214I-2148

Farin CE, Moeller CL, Sawyer HR, Gamboni F, Niswender GD (1986) Morphometric analysis of cell types in the ovine corpus luteum throughout the estrous cycle Biology of Reproduction 35 1299-1308

Farin CE, Moeller CL, Mayan H, Gamboni F, Sawyer HR and Niswender GD (1988) Effect of luteinizing hormone and buman chorionic gonadotropin on cell populations in the ovine corpus luteum Biology of Reproduction 38 413-421

Farin CE, Sawyer HR and Niswender GD (1989) Analysis of cell types in the corpus luteum of the sheep Tournal of Reproduction and Fertility 37 181-187

Fields PA and Fields MJ (1985) Ultrastructural localization of relaxin in the corpus luteum of the nonpregnant, pseudopregnant, and pregnant pig Biology of Reproduction $321169-1179$

Fields MJ. Fields PA, Castro-Hernandez A and Larkin LH (1980) Evidence for relaxin in corpora lutea of late pregnant cows Endocrinology 107 869-876
Fields MJ. Dubois W and Fields PA (1985) Dynamic features of luteal secretory granules: ultrastructural changes during the course of pregnancy in the cow Entocrinology 117 1675-1682

Fields MJ, Barros CM, Watkins WB and Fields PA (1992) Characterization of large luteal cells and their secretory granules during the estrous cycle of the cow Biology of Reproduction $46535-545$

Fitz TA, Mayan MH, Sawyer HR and Niswender GD (1982) Characterization of two steroidogenic cell types in the ovine corpus luteum Biology of Reproduction 27 703-711

Gemmell RT, Stacy BD and Thorburn GD (1974) Ultrastructural study of secretory granules in the corpus luteum of the sheep during the estrous cycle Biology of Reproduction 11 $447-462$

Gemmell RT, Stacy BD and Thorburn GD (1976́) Morphology of the regressing corpus luteum in the ewe Biology of Reproduction $14270-279$

Guldenaar SEF, Wathes DC and Pickering BT (1984) Immunocytochemical evidence for the presence of oxytocin and neurophysin in the large cells of the bovine corpus luteum Cell and Tissue Research 237 349-352

Hall JA, Dailey RA, Inskeep EK and Lewis PE (1993) Influence of the corpus luteum of pregnancy on ovarian function in postpartum ewes Journal of Animal Science 71 3067-3072

Harrison LM, Kenny N and Niswender GD (1987) Progesterone production, $\mathrm{LH}$ receptors, and oxytocin secretion by ovine luteal cell types on days 6,10 and 15 of the oestrous cycle and day 25 of pregnancy Journal of Reproduction and Fertility $79539-548$

Hawkins DR, Belfiore CJ, Kile IP and Niswender GD (1993) Regulation of messenger ribonucleic acid encoding $3 \beta$-hydroxysteroid dehydrogenase/ $\Delta 5-\Delta 4$ isomerase in the ovine corpus luteum Biology of Reproduction 48 1185-1190

Ivell R and Richter D (1984) The gene for the hypothalamic peptide hormone oxytocin is highly expressed in the bovine corpus luteum; biosynthesis, structure and sequence analysis European Molecular Biology Organization Journal 3 $2351-2354$

Kendall JZ, Plopper CG and Bryant-Greenwood GC (1978) Ultrastructural immunoperoxidase demonstration of relaxin in corpora lutea from a pregnant sow Biology of Reproduction 18 94-98

Kenny N. Farin CE and Niswender GD (1989) Morphometric quantification of mitochondria in the two steroidogenic ovine luteal cell types Biology of Reproduction 40 191-196 
Knickerbocker JJ. Wiltbank MC and Niswender GD (1988) Mechanisms of luteolysis in domestic livestock Domestic Animal Endocrinology 5 91-107

Koos RD and Hansel W (1981) The large and small cells of the bovine corpus luteum; ultrastructural and functional differences Dynamics of Ooarian Function pp 197-203 Eds NB Schwartz and M Hunzicker-Dunn. Raven Press, New York

Lei AM, Chegini N and Rao CV (1991) Quantitative cell çomposition of human and bovine corpora lutea from various reproductive states Biology of Reproduction 44 1148-1156

McClellan MC, Abel JH, Jr and Niswender GD (1977) Function of lysosomes during luteal regression in normally cycling and $\mathrm{PGF}_{2 u}$-treated ewes Biology of Reproduction 16 499-512

Mapletoft RJ and Ginther OJ (1975) Adequacy of main uterine vein and the ovarian artery in the local venoarterial pathway for uterine-induced huteolysis in ewes American Journal of Veterinary Research 36 957-963

Murdoch WJ (1987) Treatment of sheep with prostaglandin $\mathrm{F}_{20}$ enhances production of a luteal chemoattractant for eosinophils American Joumal of Reproductive Immunology and Microbiology 15 52-56

Musah AI, Schwabe C, Willham RL and Anderson LL (1988) Dystocia, pelvic and cervical dilation in beef heifers after induction of parturition with relaxin combined with cloprostenol or dexamethasone Animal Reproduction Science 16 $237-248$

Musah AI, Schwabe C and Anderson LL. (1990) Relaxin, oxytocin, and prostaglandin effects on progesterone secretion from bovine luteal cells during different stages of gestation Society for Experimental Biology and Medicine 195 $255-260$

Nett TM, McClellan MC and Niswender GD (197ó) Effects of prostaglandins on the ovine corpus luteum: blood flow, secretion of progesterone and morphology Biology of Reproduction 15 66-78

Niswender GD, Schwall RH, Fitz TA, Farin CE and Sawyer HR (1985) Regulation of luteal function in domestic ruminants: new concepts Recent Progress in Hormome Research 41 101-151

O'Shea JD (1987) Heterogeneous cell types in the corpus luteum of sheep, goats and cattle Joumal of Reproduction and Ferility Supplement 34 71-85

O'Shea JD and McCoy K (1988) Weight, composition, mitosis, cell death and content of progesterone and DNA in the corpus luteum of pregnancy in the ewe Journal of Reproducfion and Ferility $83 \quad 107-117$

O'Shea JD and Wright PJ (1985) Regression of the corpus luteum of pregnancy following parturition in the ewe Acta Anatomica $12269-76$

O'Shea JD, Nightingale MG and Chamley WA (1977) Changes in small blood vesseis during cyclical luteal regression in sheep Biology of Reproduction 17 162-177

O'Shea JD, Cran DG and Hay MF (1979) The small luteal cell of the sheep Journal of Anatomy 128 239-25I

O'Shea JD, Rodgers RJ and Wright PJ (1986) Cellular composition of the sheep corpus luteum in the mid-and late luteal phases of the oestrous cycle Jounal of Reproduction and Fertility $76 \quad 585-591$

O'Shea JD, Wright PJ and Davis KE (1987) Morphometric estimation of the numbers of granulosa cells in preovulatory follicles of the ewe Australian Journal of Biological Science 40 451-457
O'Shea JD, Rodgers RJ and D'Occhio MJ (1989) Cellular com position of the cyclic corpus luteum of the cow Journal of Reproduction and Fertility $85 \quad 483-487$

O'Shea JD, Rodgers RJ, McCoy K and D'Occhio MJ (I990) Ultrastructural cytology of the cyclic corpus luteum of the cow Acta Anatomica 138 154-165

Paavola LG and Christensen AK (1981) Characterization of granule types in luteal cells of the sheep at the time of maximum progesterone secretion Biology of Reproduction 25 203-215

Roche PJ, Crawford RJ and Tregear GW (1993) A single-copy relaxin-like gene sequence is present in sheep Molecular and Cellular Endocrinology 91 21-28

Roche PJ. Crawford RJ and Tregear GW (1995) Characterization of a sheep relaxin gene sequence and isolation attempts of the bovine relaxin gene Proceedings of the Secord International Conference Hormone Relaxin p19 Eds AH MacLennan, G Bryant-Greenwood and G Tregear. World Scientific Publishing Co., Singapore

Rodgers RJ, O'Shea JD and Findlay JK (1983a) Progesterone production in vitro by small and large ovine luteal cells Journal of Reproduction and Ferfility $69113-124$

Rodgers RJ, O'Shea JD, Findlay IK, Flint APF and Sheldrick EL (1983b) Large luteal cells the source of luteal oxytocin in the sheep Endocrinology 113 2302-2304

Rodgers RJ, O'Shea JD and Bruce NW (1984) Morphometric analysis of the cellular composition of the ovine corpus luteum Joumal of Anatomy 138 757-769

Rodgers RJ. Waterman MR, Simpson ER and Magness RR (1988) Immunoblot analysis of cholesterol side-chain cleavage cytochrome P-450 and adrenodoxin in corpora lutea of cyclic and late-pregnant sheep Joumal of Reproduction and Fertility 83 843-850

Sawyer HR, Moeller CL and Kozlowski GP (1986) Immunocytochemical localization of neurophysin and oxytocin in corpora lutea Biology of Reproduction 34 543-548

Sawyer HR, Niswender KD, Braden TD and Niswender GD (1990) Nuclear changes in ovine luteal cells in response to PGF, Domestic Antimal Endocrinology 7 229-238

Schams D (1989) Ovarian peptides in the cow and sheep Journal of Reproduction and Fertility Supplement 37 225-231

Spanel-Borowski K, Ricken AM, Kress A and Huber PR (1994) Isolation of granulosa-like cells from the bovine secretory corpus luteum and their characterization in long-term culture Anatomical Recond 239 269-279

Stacy BD, Gemmel RT and Thorburn GD (1976) Morphology of the corpus luteum in the sheep during regression indaced by prostaglandin $\mathrm{F}_{2,3}$ Biology of Reproduction 14 280-291

Theodosis DT, Wooding FBP, Sheldrick EL and Flint APF (1986) Ultrastructural localisation of oxytocin and neurophysin in the ovine corpus luteum Cell and Tissue Research 243 $129-135$

Ursely J and Leymarie P (1979) Varying response to luteinizing hormone of two luteal cell types isolated from bovine corpus luteum Joumal of Endocrinology \$3 303-310

Wathes DC, Swann RW, Birkett SD, Porter DG and Pickering BT (1983) Characterization of oxytocin, vasopressin and neurophysin from the bovine corpus luteum Endocrinology $113693-698$

Weber DM, Fields PA, Romrell LJ, Tumwasorn S, Ball BA, Drost $\mathrm{M}$ and Fields MJ (1987) Functional differences between small and large luteal cells of the late-pregnant vs. nonpregnant cow Biology of Reproduction 37 685-697 